Drink. Water Eng. Sci. Discuss., https://doi.org/10.5194/dwes-2018-26

Manuscript under review for journal Drink. Water Eng. Sci.

Discussion started: 4 January 2019

(c) Author(s) 2019. CC BY 4.0 License.

\title{
1 Froth Production in Potable Water without Chemicals
}

2 Ghanim Hassan ${ }^{1}$, Robert G. J. Edyvean ${ }^{2}$

$3 \quad{ }^{1}$ Department of Water Resources Techniques, Middle Technical University, Baghdad, Iraq.

$4 \quad{ }^{2}$ Department of Chemical and Biological Engineering, The University of Sheffield, Sheffield, UK.

5 Correspondence to: Dr. Ghanim Hassan (dr.ghanim@mtu.edu.iq)

6

7

8

9

10

11

\begin{abstract}
Froth flotation is a well-known solid-liquid separation technique. Hydrophobicity is the main driving force for such processes. Hydrophobic solids attach to air bubbles and rise up while hydrophilic or less hydrophobic species settle down. Froth can be produced with chemical frothers such as alcohols and polyglycols. However, the use of chemicals limits the use of this separation method in applications such as drinking water, food, and pharmaceutical industries. Therefore, developing a technique that produces froth without adding any chemicals would be useful to such industries.
\end{abstract}

This work demonstrates that with suitable operating parameters a $27 \mathrm{~cm}$ froth height can be obtained in a $20 \mathrm{~cm}$ diameter column by using an air flow rate of $130 \mathrm{l} / \mathrm{min}$.

\section{Introduction}

Froth flotation is a physical separation method using the selective ability of particles to adhere to air bubbles rising in water (Alam and Shang, 2012). The process usually involves addition of chemical reagents to facilitate froth formation as well as attachment to the air bubble. The more hydrophobic materials are collected on the surface where a stable froth forms. The froth is skimmed to produce a "concentrate", leaving the less hydrophobic part to stay as a "tailing" in the bottom of the flotation cell. Chemicals are used for enhancing froth formation and quality, and to control the relative hydrophobicity of the particles (Alam and Shang, 2012;Zech et al., 2012).

This separation technique is widely used in industry. Historically, early use was in mining for upgrading mineral ores as a preparation to further purification techniques (Smith et al., 1993;Nagaoka et al., 1999). In the paper industry froth flotation is used to remove hydrophobic impurities such as printing inks and stickers from recycled paper (Finch and Hardie, 1999). Waste water can also be treated by this method. Fats, oils, grease and suspended solids are separated in the Dissolved Air Flotation (DAF) process (Edzwald, 2010). PVC can be separated up to $99.3 \%$ from mixtures with PET using bubble flotation (Marques and Tenório, 2000).

In biological science, bacterial strains have been separated in the laboratory using froth flotation principles for some sixty years (Boyles and Lincoln, 1958;Rubin et al., 1966;Bahr and Schugerl, 1992;Rios and Franca, 1997). Sea water in Japanese fishing ports has been purified from bacteria using the same principles (Suzuki et al., 2008).

Theoretically, both bubble and froth flotation can be used in purifying water from microorganisms as the majority of these species are hydrophobic (van Loosdrecht et al., 1987;Stenström, 1989;Zita and Hermansson, 1997;Wang et al., 2016). Assuming bacteria are evenly distributed throughout the water column a bubble rising through the water column will attach one or more bacteria in its path and lift it to the water surface. When there is no froth, the bubble will burst when reaching water surface allowing the bacterium to return back to water again. The role of froth is to prevent the bubble from bursting and keep the bacteria attached to it long enough for it to be collected.

Using froth flotation for removing microorganisms from water could decrease the use of biocides in water treatment which would help minimize their side effects as the formation of Disinfectant by-Products (DBPs) represents a serious threat to public health in the drinking water industry (Richardson and Postigo, 2015;Ngwenya et al., 2013). The other drawback of chemical disinfection is the formation of biofilm which is a defensive strategy of bacteria against biocides (Chandra et al., 2001;Flemming, 2008;Simoes et al., 2010;Kim et al., 2012). 
Drink. Water Eng. Sci. Discuss., https://doi.org/10.5194/dwes-2018-26

Manuscript under review for journal Drink. Water Eng. Sci.

Discussion started: 4 January 2019

(c) Author(s) 2019. CC BY 4.0 License.

\section{Hypothesis}

Froths are a liquid surface phenomenon formed as a result of lowering the water surface tension which otherwise prevents bubbles from forming by pulling their molecules to the water surface (Chu et al., 2017). Well-built bubbles can be formed near walls during boiling or pumping air into water. This indicates that when a rising bubble finds a support from one side it will not burst at the surface.

Assuming a layer of adjacent bubbles covering the entire cross sectional area of a contained column rises up through the liquid to the surface, the outer row will be attached to the container wall while first inner row will be supported by the outer row and so on till the central bubble. Thus, the first layer of froth can be formed.

If a second layer of bubbles comes up through the water to the water surface, this second layer will displace the first upward. This will form a froth of two layers, and so on till a "stable" froth height controlled by operational variables is formed. Investigating the operational variables for a given column dimension should enable a maximum froth height to be determined.

At early stages of air pumping gaseous concentration is low. The first air doses "bubbles" are consumed in water. Once the air concentration in water reaches certain level, bubbles will be interring to water body and leave as it is. Bubbles start to jam at the water surface, hence a rich froth.

On the other hand, the first wave of pumped air or Oxygen is consumed and dissolved by water. During this, no froth is built because rising bubble is depleted through water column. After reaching saturation concentration, every entering bubble will keep its structure till arriving to water surface. Bubble jam starts now to be obtained and froth should be started to form.

Or, in equations:

66 According to Fick's law:

$67 \mathrm{~J}=-\mathrm{D} \frac{\partial C}{\partial x}$

Where:

$\mathrm{J}$ : is the diffusion flux (mole $\mathrm{m}^{-2} \mathrm{~s}^{-1}$ )

70 D: is the diffusion coefficient $\left(m^{2} s^{-1}\right)$

$71 \mathrm{C}$ : is the concentration gradient (mole $\mathrm{m}^{-3}$ )

$72 x$ : is the length vertical to $\mathrm{m}^{2}$ in $\mathrm{D}$ and $\mathrm{C}$ above $(m)$

73 Mass transfer coefficient can be expressed as (Kazim, 2012; Karimi, 2013):

$74 \quad($ rate of mass transferred $)=\mathrm{K}$ (interfacial area) $($ concentration difference $)$

75 Or in symbols:

$76 \quad N a=K_{l} a\left(C^{*}-C\right)$

77 Where $\mathrm{Na}$ is the mole flux at the interface. 
Drink. Water Eng. Sci. Discuss., https://doi.org/10.5194/dwes-2018-26

Manuscript under review for journal Drink. Water Eng. Sci.

Discussion started: 4 January 2019

(c) Author(s) 2019. CC BY 4.0 License.

79 Then: $\frac{d C}{d t}=K l a\left(C^{*}-C\right)$

80 In integral form: $\int_{\mathrm{Co}_{\mathrm{o}}}^{C} \frac{d C}{\left(C^{*}-C_{\circ}\right)}=K_{l} a \int_{t_{\mathrm{o}}}^{t} d t$

81 We get: $\ln \frac{\left(C^{*}-C\right)}{\left(C^{*}-C^{\circ}\right)}=K_{l} a\left(t-t_{o}\right)$

82 Where:

$83 K_{l} a$ : Liquid phase mass transfer coefficient $\left(\right.$ time $\left.^{-1}\right)$.

$84 \mathrm{C}^{*}$ : Gas maximum concentration that drives the mass transfer.

$85 \mathrm{C}$ : Gas concentration at time $=\mathrm{t}$.

$86 \mathrm{C}_{\mathrm{o}}$ : Gas minimum concentration that drives the mass transfer.

87 t: Time at concentration C.

$88 \mathrm{t}_{\mathrm{o}}$ : Initial time.

89 Units should be constituent. Any concentration units can be used as the left term is dimensionless. The term $\left(C^{*}-C\right)$ 90 represents the concentration difference of the gas in liquid due to bubbling process along the time $(\mathrm{t})$ while the term $91\left(C^{*}-C_{\circ}\right)$ is the driving force along the mass transfer interface. Also, it will be assumed that the bubble climbs the 92 water column fast enough to ignore the Oxygen concentration increase due to Oxygen mass transfer from water to 93 bubble. Equation 7 tells that the greater the mass transfer coefficient the faster the froth is built.

\section{Materials and methods}

\section{Froth flotation column}

A compact froth flotation column system (Figure 1) consists of a $2 \mathrm{~m}$ long transparent Perspex (Poly methyl methacrylate) tube, $20 \mathrm{~cm}$ inside diameter. A ceramic sparger, $19 \mathrm{~cm}$ diameter, with a 50-micron pore size (from HP technical ceramics) is fixed $30 \mathrm{~cm}$ above the column base. The sparger is joined to a $15 \mathrm{~mm}$ diameter tube connected to a compressor with a rotameter (10-900 1/min). Note that the system in the picture is more complicated than the drawing because it is designed to be also used in other experiments. 
Drink. Water Eng. Sci. Discuss., https://doi.org/10.5194/dwes-2018-26

Manuscript under review for journal Drink. Water Eng. Sci.

Discussion started: 4 January 2019

(c) Author(s) 2019. CC BY 4.0 License.
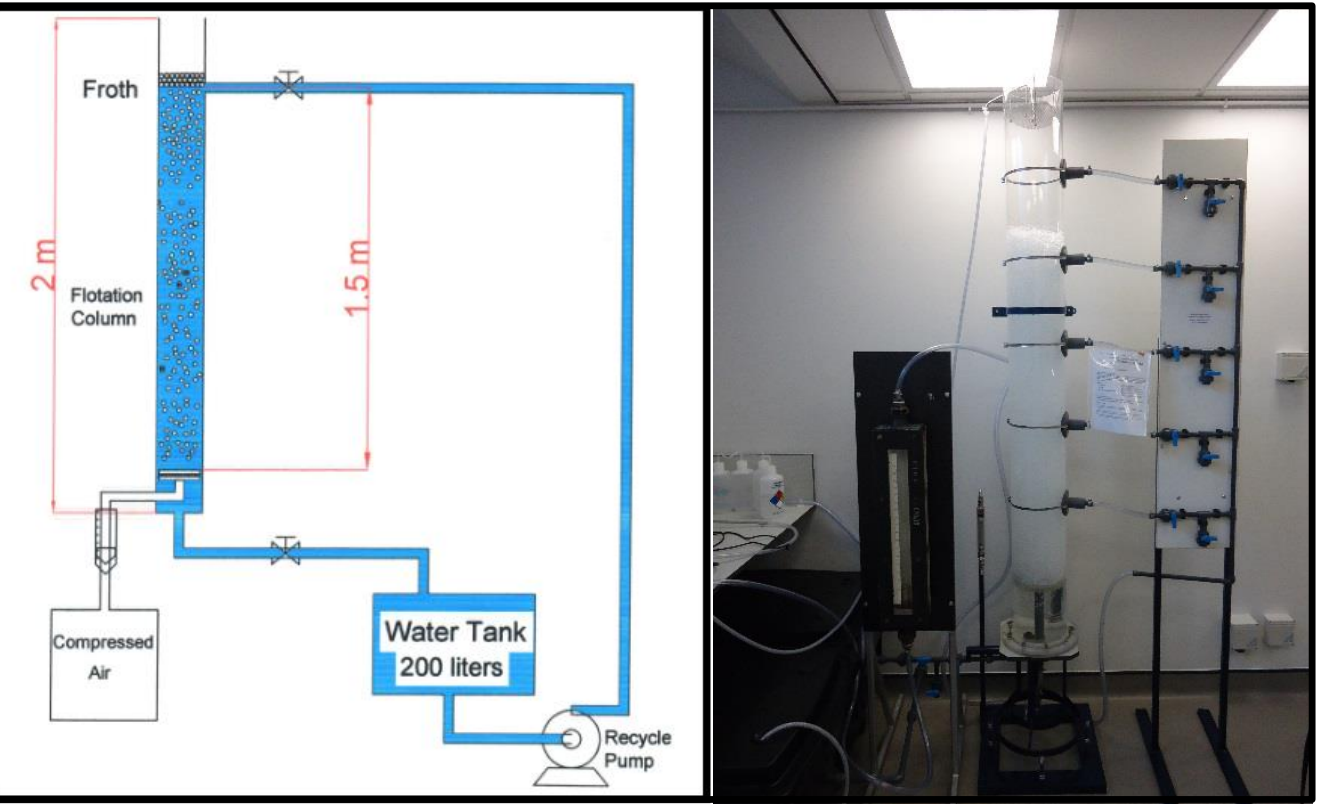

Figure 1: Froth flotation column

\subsection{Oxygen concentration measurement}

Oxygen concentration in the water was measured using an AZ-8403 Dissolved Oxygen meter produced by (AZ ${ }^{\circledR}$ ) and calibrated daily according to the method mentioned in equipment manual.

\subsection{Froth production methodology}

108 The following steps were followed to produce froth of various heights in the column:

109 1- With an empty column, start air blowing at the rate of $\mathrm{L} \mathrm{min}^{-1}$.

110 2- Start water pumping at $1 \mathrm{~L} \mathrm{~min}^{-1}$.

111 3- Once water level reaches $15 \mathrm{~cm}$ above the sparger, stop water pumping.

112 4- Measure for froth height.

113 5- Rise up air pumping to $30 \mathrm{~L} \mathrm{~min}^{-1}$.

114 6- Measure for froth height. And so on till completing the full range of air flow rates to 210

$115 \mathrm{~L} \mathrm{~min}^{-1}$

116 7- Start water pumping again at $1 \mathrm{~L} \mathrm{~min}^{-1}$ till reaching $30 \mathrm{~cm}$ above the sparger, and then

117 stop it.

118 8- Repeat steps 4 through 7 for every $15 \mathrm{~cm}$ of water height over sparger till completing the 
Drink. Water Eng. Sci. Discuss., https://doi.org/10.5194/dwes-2018-26

Manuscript under review for journal Drink. Water Eng. Sci.

Discussion started: 4 January 2019

(c) Author(s) 2019. CC BY 4.0 License.

\section{Results}

\subsection{Effect of air pumping on oxygen solubility}

122

Air was pumped continuously through the water column with a water level of $45 \mathrm{~cm}$. This is to estimate the increase of dissolved Oxygen as a result of pumping a large amount of air through the water column. The results are given in figure 2. The general trend of the Oxygen concentration with time was a rise within the first 5 minutes then followed by a fluctuation between 5 and 30 minutes' till reaching a plateau after 30 minutes. More pumped air led to higher dissolved Oxygen levels.

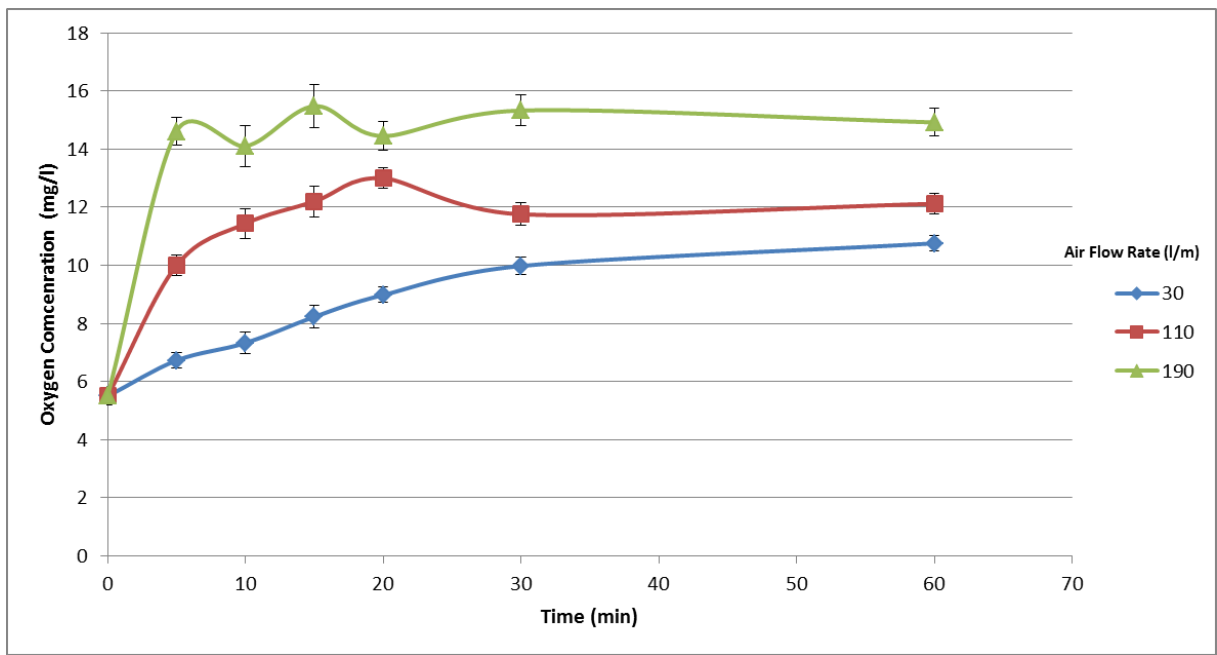

Figure 2: Effect of air pumping on Oxygen solubility

Substituting figure 2 in equation 7 with taking the values of $\mathrm{C}^{*}$ of $40 \mathrm{mg} \mathrm{L}^{-1}$ and $\mathrm{C}_{\mathrm{o}}$ of $5.5 \mathrm{mg} \mathrm{L}^{-1} K_{l} a$ for oxygen dissolution in water can be presented by figure 3 .

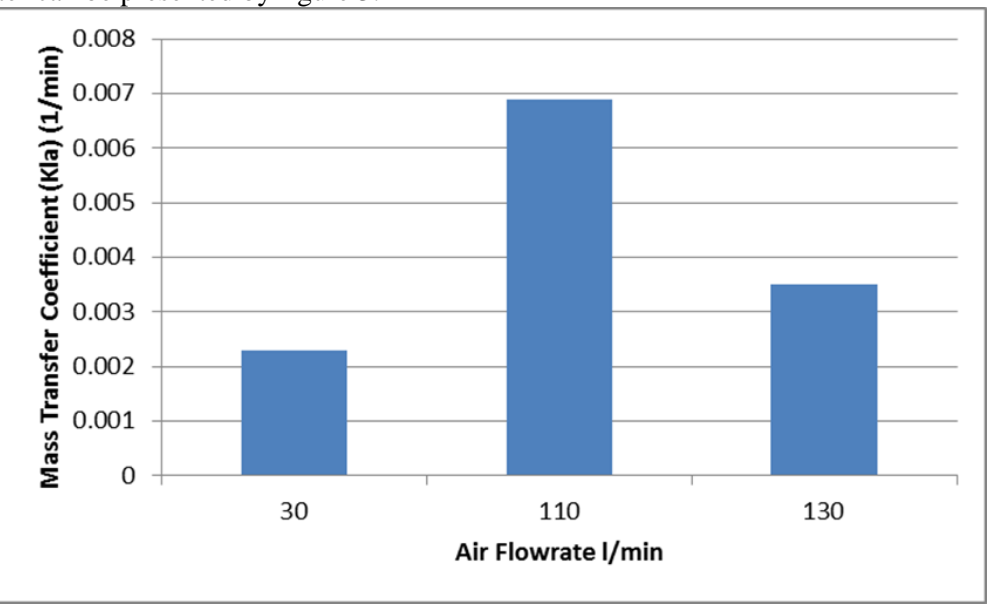

Figure (3): The relation between air flowrate and mass transfer coefficient $\left(K_{l} a\right)$ 
Drink. Water Eng. Sci. Discuss., https://doi.org/10.5194/dwes-2018-26

Manuscript under review for journal Drink. Water Eng. Sci.

Discussion started: 4 January 2019

(c) Author(s) 2019. CC BY 4.0 License.

\subsection{Effect of air flow rate and water level on froth height}

Figure 4 shows the variation in froth height with air flow rate and water height in a $20 \mathrm{~cm}$ (ID) column. Table 1 gives the error margins of Figure 4 in centimeters.

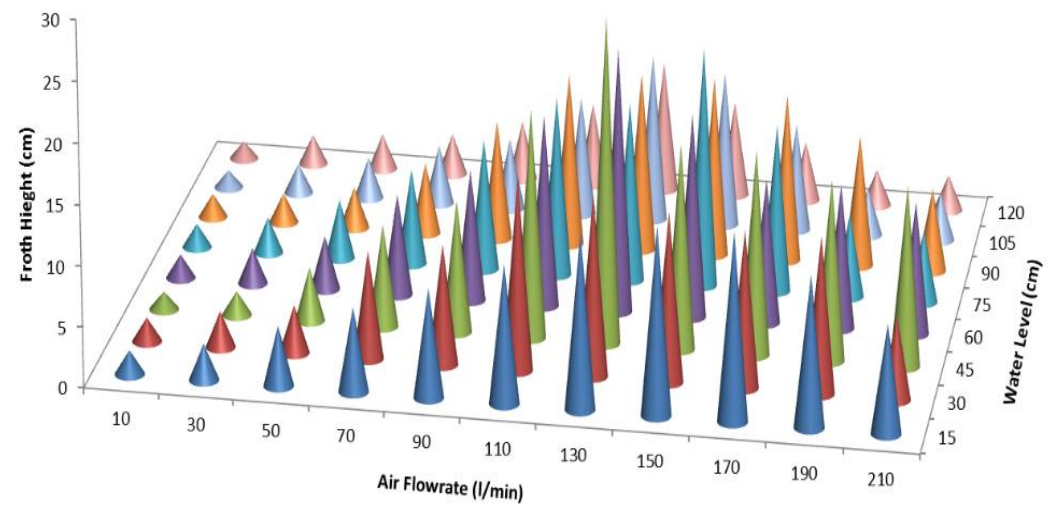

Figure 4: Effect of air flow rate and water level on froth height

Table 1: Error margins in $( \pm \mathrm{cm})$ related to figure 4

\begin{tabular}{|c|c|c|c|c|c|c|c|c|c|c|c|c|}
\hline & \multicolumn{11}{|c|}{ Air Flow Rate (1/m) } \\
\hline & & 10 & 30 & 50 & 70 & 90 & 110 & 130 & 150 & 170 & 190 & 210 \\
\hline \multirow{8}{*}{ 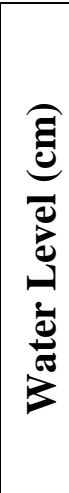 } & 15 & \pm 0.13 & \pm 0.18 & \pm 0.22 & \pm 0.25 & \pm 0.25 & \pm 0.25 & \pm 0.36 & \pm 0.41 & \pm 0.44 & \pm 0.45 & \pm 0.49 \\
\hline & 30 & \pm 0.15 & \pm 0.23 & \pm 0.25 & \pm 0.33 & \pm 0.35 & \pm 0.36 & \pm 0.35 & \pm 0.55 & \pm 0.55 & \pm 0.57 & \pm 0.64 \\
\hline & 45 & \pm 0.23 & \pm 0.25 & \pm 0.31 & \pm 0.35 & \pm 0.35 & \pm 0.35 & \pm 0.52 & \pm 0.73 & \pm 0.77 & \pm 0.81 & \pm 0.90 \\
\hline & 60 & \pm 0.32 & \pm 0.35 & \pm 0.45 & \pm 0.45 & \pm 0.55 & \pm 0.55 & \pm 0.93 & \pm 1.12 & \pm 1.12 & \pm 1.21 & \pm 1.32 \\
\hline & 75 & \pm 0.35 & \pm 0.43 & \pm 0.45 & \pm 0.57 & \pm 0.63 & \pm 0.68 & \pm 0.95 & \pm 1.15 & \pm 1.15 & \pm 1.34 & \pm 1.44 \\
\hline & 90 & \pm 0.60 & \pm 0.65 & \pm 0.72 & \pm 0.75 & \pm 0.85 & \pm 0.85 & \pm 1.51 & \pm 1.59 & \pm 1.80 & \pm 2.05 & \pm 2.10 \\
\hline & 105 & \pm 0.82 & \pm 0.85 & \pm 0.91 & \pm 0.95 & \pm 1.05 & \pm 1.05 & \pm 1.24 & \pm 1.43 & \pm 2.30 & \pm 2.45 & \pm 2.58 \\
\hline & 120 & \pm 0.91 & \pm 0.95 & \pm 1.04 & \pm 1.05 & \pm 1.15 & \pm 1.15 & \pm 1.35 & \pm 1.91 & \pm 2.42 & \pm 2.50 & \pm 2.65 \\
\hline
\end{tabular}


Drink. Water Eng. Sci. Discuss., https://doi.org/10.5194/dwes-2018-26

Manuscript under review for journal Drink. Water Eng. Sci.

Discussion started: 4 January 2019

(c) Author(s) 2019. CC BY 4.0 License.

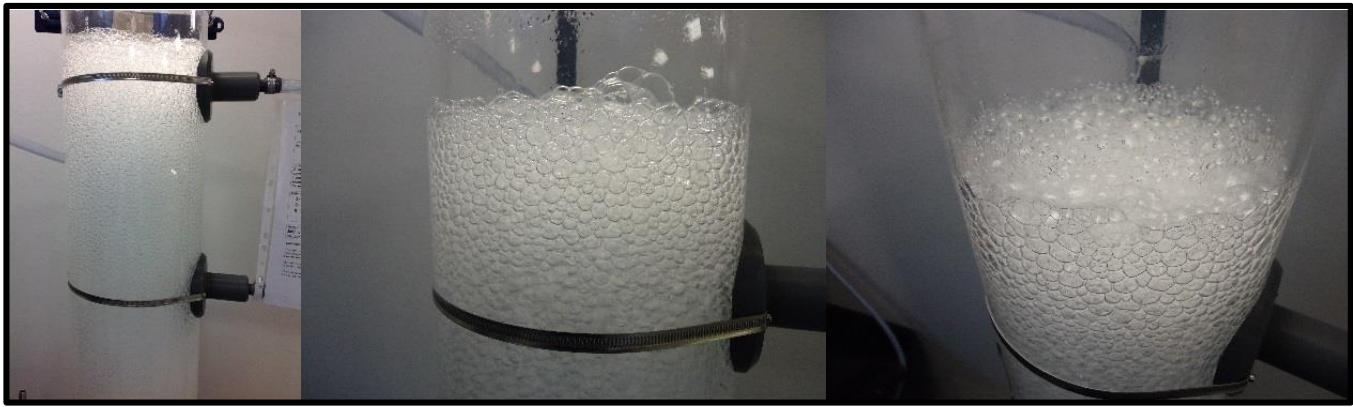

Figure 5: Left, froth in its optimum height (distance between belts is $30 \mathrm{~cm}$ ). Middle, close view for the upper part of froth. Right, view for froth surface

\section{Discussion}

\subsection{Oxygen solubility in water}

In the early stages excess air leads to increase dissolved air in the water. This increase is not a one-way phenomenon. Once an air molecule passes to water, the tendency of an existing one to release out of the water will increase. Forward action "solution" is fast; while reverse movement "de- solution" is slow. As air pumping increases, there are fluctuations with increases and decreases with time until a steady state is reached (Figure 2).

\subsection{Effect of air flow rate and water level on froth height}

Air pumping parameters are the main factors leading to froth formation without chemicals. More air with less water leads to faster and richer froth building. While more water with less air leads to slow or no froth. This is because, at first, air is consumed by dissolving into the water. Air solution in water is relatively slow which makes froth formation nearly impossible when starting air pumping in a water filled column. To overcome this it is recommended to minimize water inlet and maximize air pumping. A water to air ratio of 1:130 was found to be optimum in the operating conditions in this work. 
Drink. Water Eng. Sci. Discuss., https://doi.org/10.5194/dwes-2018-26

Manuscript under review for journal Drink. Water Eng. Sci.

Discussion started: 4 January 2019

(c) Author(s) 2019. CC BY 4.0 License.

Higher air flow rates have two counteractive effects on froth height. More air builds a higher froth; but it increases water turbulence which destroys froth. Balancing these two factors the optimal flow rate was found to be $1301 / \mathrm{min}$ for a column with an internal diameter of $20 \mathrm{~cm}$ using a water level of $45 \mathrm{~cm}$. Larger diameters need greater air flow rates to keep the same air velocity across the column; that is, $0.069 \mathrm{~m} / \mathrm{s}$.

This study is trying to avoid the limitations of two previous industrial applications, Dissolved Air Flotation (DAF) and froth flotation. In water industry DAF is limited to removal of solid contaminants rather than microorganisms. DAF depends on pumping air into water and keeping it under high pressure. Under this high pressure, solubility of air in water increases. When this water inters the DAF tank, the pressure returns to atmospheric and air starts to release from water as a micro bubble. The amount of micro bubbles is limited to $0.007 \mathrm{~m}^{3} / \mathrm{m}^{3}$ in best conditions depending on the applied pressure (Miettinena et al., 2010); which in turn, limits the whole operation efficiency if it is desired to be used for removing microorganisms. In DAF froth is not that important because the separated species will stay at water surface by buoyancy. Furthermore, the flow regime in separation tanks is nearly laminar, so these species will not return back to water bulk body. Due to this, the main defect of DAF is its relative slowness; hence it cannot be used for further purification in drinking water industry.

In mineral froth flotation there is more freedom to use direct air pumping but this causes turbulence; which remixes the separated particles with the water. This is where the importance of developing a stable froth comes from. But, more air pumping leads to froth destruction, which limits the air to liquid ratio to $10 \mathrm{~m}^{3} / \mathrm{m}^{3}$ (Miettinena et al., 2010) and leads to the use of chemical frothers. The froth cannot be formed without chemical frothers because of the wide cross sectional area of flotation cells, which leaves the rising bubble without support when reaching water surface, hence bursting.

A large air to water ratio will help to produce more bubbles per volume of water; hence the probability for forming bubble layers that reach the water surface will increase. Thus a column with sufficient air pumping is able to form a stable froth.

Two variables were optimized in this work; first is air flow rate, where froth height increased as flow was increased until an optimum flow rate of $130 \mathrm{l} / \mathrm{min}$. For air flow rates of $150 \mathrm{l} / \mathrm{min}$ and above, the froth height starts to decrease because of high turbulence.

For the second variable; water level, the optimum value was $45 \mathrm{~cm}$ above the air sparger. At lower water levels, air pumping from the sparger neutralizes the horizontal disturbance of water surface. Above $60 \mathrm{~cm}$ the amount of water inside the column becomes too big to be neutralized with the amount of pumped air available. More air leads to more turbulence, hence low froth height.

\section{Conclusions}

A well-built froth can be produced in a column of suitable diameter and water level. This can be used to separate particles/bacteria by froth flotation without adding any chemicals that may affect water quality. By avoiding using chemical frothers hydrophobic particles can be separated in many industries like drinking water, food and pharmaceutical industries.

\footnotetext{
Alam, R., and Shang, J. Q.: Effect of operating parameters on desulphurization of mine tailings by froth flotation, J Environ Manage, 97, 122-130, 10.1016/j.jenvman.2011.11.013, 2012.

Bahr, K. H., and Schugerl, K.: Recovery of Yeast from Cultivation Medium by Continuous Flotation and its Dependence on Cultivation Conditions, Chemical Engineering Science, 74, 11-20, 1992.

Boyles, W. A., and Lincoln, R. E.: Separation and concentration of bacterial spores and vegetative cells by foam flotation, Appl Microbiol, 6, 327-334, 1958.

Chandra, J., Kuhn D. M., Mukherjee, P. K., Hoyer, L. L., McCormick T., and A., G. M.: Biofilm Formation by the Fungal PathogenCandida albicans: Development, Architecture, and Drug Resistance, Journal of Bacteriology 183, 5385-5394, 2001.

Chu, P., Pax, R., Li, R., Langlois, R., and Finch, J. A.: Using Sound To Study the Effect of Frothers on the Breakaway of Air Bubbles at an Underwater Capillary, Langmuir : the ACS journal of surfaces and colloids, 33, 3200-3207, 10.1021/acs.langmuir.7b00114, 2017.
} 
Drink. Water Eng. Sci. Discuss., https://doi.org/10.5194/dwes-2018-26

Manuscript under review for journal Drink. Water Eng. Sci.

Discussion started: 4 January 2019

(c) Author(s) 2019. CC BY 4.0 License.

Edzwald, J. K.: Dissolved air flotation and me, Water Res, 44, 2077-2106, 10.1016/j.watres.2009.12.040, 2010.

Erdtman, E., Bohlén, M., Ahlström, P., Gkourmpis, T., Berlin, M., Andersson, T., and Bolton, K.: A molecular-level computational study of the diffusion and solubility of water and oxygen in carbonaceous polyethylene

nanocomposites, Journal of Polymer Science Part B: Polymer Physics, 54, 589-602, 10.1002/polb.23951, 2016.

Finch, J. A., and Hardie, C. A.: An example of innovation from the waste management industry: Deinking flotation cells, Minerals Engineering, 12, 467-475, http://dx.doi.org/10.1016/S0892-6875(99)00030-8, 1999.

Finch, J. A., and Zhang, W.: Frother function-structure relationship: Dependence of CCC95 on HLB and the Hratio, Minerals Engineering, 61, 1-8, http://dx.doi.org/10.1016/j.mineng.2014.02.006, 2014.

Flemming, H. C.: Why Microorganisms Live in Biofilm and the Problem of Biofouling, Springer-Verlag Berlin Heidelberg, 2008.

Hanotu, J., Bandulasena, H. C., and Zimmerman, W. B.: Microflotation Performance for Algal Separation,

Biotechnology and Bioengineering, 2012.

Harris, M. C., and O'Connor, C. T.: Characterization of frothers and their behavior using partial molar Excess Gibbs energy, International Journal of Mineral Processing, 158, 63-67, https://doi.org/10.1016/j.minpro.2016.11.018, 2017. Kim, J., Park, H. D., and Chung, S.: Microfluidic Approaches to Bacterial Biofilm Formation, Molecules, 98189834, 2012.

Marques, G. A., and Tenório, J. A. S.: Use of froth flotation to separate PVC/PET mixtures, Waste Management, 20, 265-269, http://dx.doi.org/10.1016/S0956-053X(99)00333-5, 2000.

Miettinena, T., Ralstonb, J., and Fornasiero, D.: The limits of fine particle flotation, Minerals Engineering, 23, 420437, 2010.

Nagaoka, T., Ohmura, N., and Saiki, H.: A Novel Mineral Flotation Process Using Thiobacillus ferrooxidans, Applied and Environmental Microbiology, 65, 3588-3593, 1999.

Ngwenya, N., Ncube, E., and Parsons, J.: "Recent Advances in Drinking Water Disinfection: Successes and Challenges", in: Reviews of Environmental Contamination and Toxicology, edited by: Whitacre, D. M., Reviews of Environmental Contamination and Toxicology, Springer New York, 111-170, 2013.

Norori-McCormac, A., Brito-Parada, P. R., Hadler, K., Cole, K., and Cilliers, J. J.: The effect of particle size distribution on froth stability in flotation, Separation and Purification Technology, 184, 240-247, https://doi.org/10.1016/j.seppur.2017.04.022, 2017.

Richardson, S. D., and Postigo, C.: CHAPTER 1: The Next Generation of Drinking Water Disinfection ByProducts: Occurrence, Formation, Toxicity, and New Links with Human Epidemiology, in: Disinfection Byproducts in Drinking Water, The Royal Society of Chemistry, 1-13, 2015.

Rios, E. M., and Franca, C. E.: On the use of froth flotation on the recovery of Bacillus sphaericus spores, Braz. J. Chem. Eng., 14, 1997.

Rubin, A. J., Casse E. A., Handerson O., Johnson J. D., and C., L. J.: Microflotation: New low gas-flow rate foam separation technique for bacteria and algae, Biotechnology and Bioengineering, 8, 135-151, 1966.

Simoes, M., Lucia C. Simoes, and Vieira, M. J.: A review of current and emergent biofilm control strategies, Food Science and technology, 43, 573-583, 2010.

Smith, R., Misra, M., and Chen, S.: Adsorption of a hydrophobic bacterium onto hematite: Implications in the froth flotation of the mineral, Journal of Industrial Microbiology, 11, 63-67, 10.1007/BF01583676, 1993.

Stenström, T. A.: Bacterial hydrophobicity, an overall parameter for the measurement of adhesion potential to soil particles, Appl. Environ. Microbiol, 55, 1989.

Suzuki, Y., Hanagasaki N Fau - Furukawa, T., Furukawa T Fau - Yoshida, T., and Yoshida, T.: Removal of bacteria from coastal seawater by foam separation using dispersed bubbles and surface-active substances, 2008.

van Loosdrecht, M. C., Lyklema, J., Norde, W., Schraa, G., and Zehnder, A. J.: The role of bacterial cell wall hydrophobicity in adhesion, Applied and Environmental Microbiology, 53, 1893-1897, 1987.

Wang, G., Nguyen, A. V., Mitra, S., Joshi, J. B., Jameson, G. J., and Evans, G. M.: A review of the mechanisms and models of bubble-particle detachment in froth flotation, Separation and Purification Technology, 170, 155-172, https://doi.org/10.1016/j.seppur.2016.06.041, 2016.

Zech, O., Haase, M. F., Shchukin, D. G., Zemb, T., and Moehwald, H.: Froth flotation via microparticle stabilized foams, Colloids and Surfaces A: Physicochemical and Engineering Aspects, 413, 2-6, http://dx.doi.org/10.1016/i.colsurfa.2012.04.024, 2012.

Zita, A., and Hermansson, M.: Determination of bacterial cell surface hydrophobicity of single cells in cultures and in wastewater in situ, FEMS Microbiol Lett, 152, 299-306, 1997. 